A Keynote Speech at the East Asian Law and Society Conference 2015,

Waseda University, Tokyo

4-6 August 2015

\title{
Human Rights, the Rule of Law and Democracy: Recent Experience of Hong Kong and China
}

Professor Johannes Chan, SC (Hon)

Faculty of Law, The University of Hong Kong

Keywords: Rule of Law, arbitrary powers, independence of the judiciary, human rights, civil disobedience, rule of law and evolving democracy, significance of the rule of law in Asia, legislative interpretation, $4^{\text {th }}$ Plenum of the $18^{\text {th }}$ Central Committee of the Chinese Communist Party, legitimacy of constitutional review, China and Hong Kong, One Country, Two Systems, Basic Law

\section{Introduction}

Human rights discourses in the western world and in Asia assume very different roles. In the West, or more accurately, in developed democracies, the role of human rights discourses is largely to fine tune the social and political developments and to redress the balance between popular democracy on the one hand and democratic dictatorship on the other. In Asia, particularly among the developing economies, human rights discourses could have a disturbing role as they from time to time query the legitimacy of the ruling regime, and the focus of the discourses in Asia is more about maintaining national security/public order and promoting economic development rather than minority protection and non-discrimination. To some extent this tension underlines the debates on the universality and cultural relativity of human rights in the early nineties of the last century, the 
debate of which being most intense in the Asian region. ${ }^{1}$ It is not the intention of this paper to go into this interesting debate, save to note that the debate has died down since the dawn of the new millennium, coupled with the emergence of a rule of law discourse, which is considered to be indispensable for economic development and which seems to be readily embraced by many developing economies in Asia. The successful experience of China in economic reform in the past two decades has inspired many developing economies in Asia. In 2014, China for the first time convened a Plenum of the Central Committee of the Communist Party with a theme on the rule of law. Critics have been quick to point out the difference between the rule of law and the rule by law in China, and that the rule of law in China is upheld on the condition of upholding the central leadership of the Communist Party. Nonetheless, the message on the rule of law is important, not only for China, but also many parts of Asia.

In the meantime, frustration at the lack of progress of democracy and the incompetence of the governing regime has led to conflicts in many parts of Asia, sometimes conflicts which involved a certain extent of violence. Yet there are also conflicts the leaders of which advocated opposition of a nonviolent nature. The Umbrella Movement that broke out in Hong Kong in the autumn of 2014 was a mass protest against a skewed proposal for the election of the Chief Executive, which took the form of occupation and blockage of the main thoroughfares in the commercial/financial districts for 79 days. The protesters emphasized that it was a peaceful and non-violent movement in the nature of civil disobedience. A similar, albeit of a much shorter duration, Sunflower Movement broke out in Taiwan earlier that year. Opposition to the Umbrella Movement soon pointed out that such unlawful act of occupation would destroy the very fabrics of the rule of law; the Government repeatedly called upon the protesters to "obey the law", whereas supporters argued that the rule of law means far more than just blind adherence to laws, and that there is at least a moral "right" to disobey the law when the law transgresses certain fundamental values. This has triggered an intense debate on the rule of law and civil disobedience.

See, for example, the Bangkok Declaration 1993. 
These parallel developments highlight not only the tension between human rights, democracy and the rule of law within a society, but also the chasms that reflect political and ideological gaps in the understanding of these issues between two different legal systems and societies, albeit under one sovereign. The tension between Hong Kong and China is particularly interesting, as one represents a modern developed economy that is entrenched in a western liberal common law tradition and subscribes to the doctrine of separation of powers, whereas the other represents a rising global economic power that emphasizes central planning and party leadership under a socialist regime. The gap in the understanding of the rule of law leads to inevitable conflicts when the two systems are brought together under the model of "One Country, Two Systems".

\section{The Rule of Law: an elusive concept?}

The rule of law is to some extent an elusive concept in the sense that no single definition has been regarded as satisfactory. Indeed, it has been used to mean very different things by different people at different times, leading Professor Tamanaha to criticize this "rampant divergence of understandings" as "analogous to the notion of the Good in the sense that 'everyone is for it, but have contrasting convictions about what it is."'2 $\mathrm{He}$ is in good company of Professors Joseph Raz and Professor John Finnis, who respectively criticized the abuse of using this notion to refer to anything good about a legal system. ${ }^{3}$ Perhaps the harshest criticism of the notion of the rule of law comes from Professor Judith Shklar, who described the term as "just another one of those self-congratulatory rhetorical devices that grace the public utterances of Anglo-American politicians." ${ }^{4}$

While there is some truth in these criticisms, it should not diminish the value and the potent impact of this concept, especially in places when the rule of law

\footnotetext{
${ }^{2}$ Tamanana, On the Rule of Law, p 3. For a recent discussion of the concept of the rule of law, see Tom Bingham, The Rule of Law (Allen Lane, 2010).

3 Joseph Raz, "The Rule of Law and its Virtue", in J Raz, The Authority of Law: Essays on Law and Morality (Oxford University Press, 1979), p 210, and John Finnis, Natural Law and Natural Rights (Oxford University Press, 1980), p 270.

4 Judith Shklar, "Political Theory and the Rule of Law", in A Hutchinson and P Monahan (eds), The Rule of Law: Ideal or Ideology (Toronto: Carswell, 1987), p 1.
} 
is likely to be threatened. Thus, in the Asian region when the rule of law is most frequently honoured by its breach, when the legal system of many jurisdictions is still at a rudimentary stage of development, when coup d'tat is a regular phenomenon, when arbitrary arrest and detention is a daily occurrence, when economic development is emphasized the expense of personal liberty and security, and when procedural fairness is readily sidestepped or ignored in the name of national security or public order, the concept of the rule of law bears a particular significance and provides a powerful yardstick for assessing such encroachment. This is of course not restricted to the Asian Region. Just look around the world how the due process of law is compromised in many countries in the name of anti-terrorism. Thus, it is argued that, despite its elusive content, the rule of law has a core content and continues to assume an important role in the debate on constitutionalism in modern era, and is of particular significance in this part of the world where the concept could provide a powerful check against arbitrary governance, whereas the same discourse in the West serves more of a function of fine-tuning the system.

Then, what is the core content of this concept of the rule of law?

\section{The Rule of Law and Arbitrary Powers}

First, the rule of law embodies the supremacy of law and the absence of arbitrary powers. Law provides the legal basis and confers legitimacy on government actions. The absence of law encourages arbitrary exercise of powers. The rule of law confines the exercise of those powers to the purposes for which the powers are granted in the first place. It stems from the idea that power corrupts, and absolute power corrupts absolutely. As Dr Thomas Fuller stated in 1733, "Be you never so high, the Law is above you." ${ }^{5}$ Gone are the days when the King could claim a divine power; likewise, no government, military or otherwise, and no government officials or political party is above the law. To many countries that are still in the process of building up their legal systems, or that are still governed by military or one-party regimes, the rule of law serves as a timely reminder of the constraints of government powers.

\footnotetext{
${ }^{5}$ Quoted by Lord Denning in Gouriet v Union of Post Office Workers [1977] QB 729, 762.
} 
Secondly, the absence of arbitrary exercise of powers leads to another important aspect of the rule of law, namely, equality before the law. General law is to be enforced equally and fairly. This does not mean that there could not be law for a special group of people, such as the minors, the bankrupt, or the minority shareholders. However, in general, the same law applies to everyone, be he a high government official, a senior party member or an ordinary citizen. The Government, like any other citizen, is exposed to the same consequences of the law of contract or the law of tort. As Professor Dicey put it, " no man is above the law, but... every man, whatever be his rank or condition, is subject to the ordinary law of the realm and amenable to the jurisdiction of the ordinary tribunal.." ${ }^{\prime 6}$ The rule of law leaves no room for favouritism or privilege.

Thirdly, the existence of law is not sufficient. The law is there to confine the arbitrary exercise of powers. It follows that minimum safeguards and a fair and due process are called for when freedom and liberty are curtailed or when adverse decisions are made against an individual. It is probably unnecessary to go back to the Magna Carta 1215, feebly sealed by the reluctant King John, that "no free man shall be seized or imprisoned or stripped of his rights or possession ... except by the lawful judgment of his equals or by the law of the land." ${ }^{7}$ Professor Albert Dicey, in his monumental work on An Introduction to the Study of the Law of the Constitution, put it this way: "no man is punishable or can lawfully be made to suffer in body or goods except for a distinct breach of law established in the ordinary legal manner before the ordinary courts of the land." ${ }^{8}$ Notwithstanding numerous academic discussions of and challenges to Dicey's formulation, this core message is clear and has time and again been endorsed by jurists and judges of the highest distinction in different parts of the world. ${ }^{9}$

Thus, if the law confers a discretionary power, the power has to be exercised reasonably, fairly and in good faith. When the law confers a power on the police to question a suspect, that power does not include a power to extract a

\footnotetext{
${ }^{6}$ A V Dicey, An Introduction to the Study of the Law of Constitution (Macmillan, 19 ${ }^{\text {th }}$ ed, 1945), p 193.

${ }^{7}$ Lord Irvine argued forcefully that Magna Carta remains the foundation stone of the rule of law and continues to underpin key constitutional principles: Lord Irvine of Lairg, "The spirit of Magna Carta continues to resonate in modern law" [2003] LQR 227.

${ }^{8}$ A V Dicey, ibid, p 188.

${ }^{9}$ See Tom Bingham, The Rule of Law (Allen Lane, 2010), p 6.
} 
confession with force. If the law confers a power of arrest, that power has to be exercised on the basis of reasonable suspicion. If the law confers a power on a public body to make decisions that may have adverse consequences on the people affected by such a decision, such as the making of a resumption order resuming private land for public good, or the revocation of a licence to run a business, that power can only be exercised after affording the person affected an opportunity to be heard, and if necessary, after following a fair and impartial hearing that affords the protection of due process. As Lord Steyn put it, "unless there is the clearest provision to the contrary, Parliament must be presumed not to legislate contrary to the rule of law. And the rule of law enforces minimum standards of fairness, both substantive and procedural." ${ }^{10}$

Fourthly, in order to minimize the arbitrariness of the law, law has to be adopted by a formal process, be accessible to those affected by it, and its consequences have to be reasonable foreseeable, if necessary with legal advice, so that people can know what the law is in order to comply with the law. Retrospective application of law is generally unfair. Law has to be published. Confidential documents, internal directives or administrative guidelines are not law. Government policies are not law. Notwithstanding the digital age, the laws in many Asian jurisdictions are still difficult to be found. Some are written in a language that is not readily understandable to the majority of the public. Some bear no relations to the actual practice, as there could be a wide gap between what the law says and what the practice is. Some are drafted in such vague language that it confers absolute or blanket powers on the executive government. A law which says that whatever the Government regards as lawful is lawful, or that the Government has absolute discretion to determine what the law means, is not law at all.

This leads to another important aspect of the rule of law: the absence of arbitrary powers implies the fair and proper enforcement of the law, and the availability of timely redress and remedies when there is a violation of the law. Law without remedy is like a pious declaration. It is nice for show but it has no real meaning! Sadly this aspect of the rule of law is most frequently undermined, if not ignored, in many developing economies where compliance with the rule of law is demonstrated by the number of new statutes that have

${ }^{10} R$ v Secretary of State for the Home Department, ex parte Pierson [1998] AC 539, at 591. 
been enacted, whereas there is disturbing silence about how they are implemented. Fair enforcement of the law requires training of the law enforcement officers as well as the existence of and a right of access to a proper mechanism for redress. There are of course many different models for seeking redress, but an indispensible one would be a right of access to a court staffed by an independent and impartial judiciary. There has to be systemic guarantees for the independence of the judiciary. In the common law system, it is a trite principle of constitutional status that if there is a right, there is a remedy. Professor Dicey once said that the Habeas Corpus Acts "declare no principle and define no right, but they are for practical purposes worth a hundred constitutional articles guaranteeing individual liberty". ${ }^{11}$ This may be an over-statement as legislative encroachment of fundamental rights is not as prevalent at his time than it is today, but it does highlight the importance of the practical dimension of the rule of law, and focuses our minds on the issue of enforcement and remedies. In some countries, the right of access to court and a right to remedy are entrenched in a constitution, but sadly, there is also no shortage of jurisdictions, China included, where there is no means to enforce a constitution. ${ }^{12}$

Finally, the rule of law embodies certain fundamental values. I have already alluded to some procedural aspects of the rule of law - the right to a fair hearing, no confession extracted by force, no arrest without reasonable suspicion, a right to remedy to courts, and so on. Yet for any legal system to be legitimate, the law has to protect the fundamental rights of the people the right to liberty and security of the person, the right to free speech and assembly, the right to religious beliefs, the right to property, the right to equality and equal protection of the law, and so on. There may be disagreement as to the list, but there has to be a core of fundamental human rights that give legitimacy to any governing regime. Without these values, law will become naked powers, and here lies a fundamental difference between the rule of law and the rule by law. Law is an instrument to achieve common

\footnotetext{
${ }^{11}$ A V Dicey, supra, $\mathrm{n} 6$.

${ }^{12}$ In the well-known case of Chen Yu-ling, the People's Supreme Court found a cause of action in the right to education under the PRC Constitution. This case has generated hopes that it may mark the dawn of an era of constitutional review in China, but following the removal of a judge from the People's Supreme Court, the People's Supreme Court in a judicial interpretation reversed the decision and reinstated the principle that the Constitution is not actionable in court.
} 
good by protecting the people, and not an instrument to uphold a governing regime by suppressing the fundamental rights of the people. This is not to say that these rights are absolute. They could of course be restricted, but any restriction must be subject to the closest scrutiny and be justified as a rational and proportionate response to some other legitimate interests. It is all too often to hear Governments justifying a suppression of fundamental rights and liberties on the most remote concern for national security or public law or on the most flimsy piece of evidence. While national security or public order are legitimate reasons for restricting fundamental rights, these concepts could easily become a justification of arbitrary suppression of fundamental rights, unless it can be shown that the restrictions do pursue such legitimate aims, that there is a rational connection between the restrictions and the pursuit of such legitimate aims, and that the restrictions are a proportionate response to the pursuit of such legitimate aims. In many Asian jurisdictions, there is not even the slightest connection between arbitrary arrest or detention and public order or national security. Mere speeches, even if they are made in the least provocative manner, have been considered to be a threat to public order or public security. The rule of law requires the Government to substantiate such threat and to justify the restrictions as a proportionate measure. It is implicit in the concept of the rule of law, if it is to avoid arbitrary powers, to embody a degree of diversity and tolerance.

Do these western imperial values bear any relevance to Asia?

These values are found in many international instruments, such as the Universal Declaration of Human Rights and the two International Bills of Rights, to which many Asian countries are signatories. While this may bring us back to the debate on the universality or cultural relativity of human rights (and it is not the intention of this paper to re-visit this debate), it is to be noted that the rule of law has gained widespread acceptance among Asian Governments. Discourses on human rights convey a disturbing if not also an emotive overtone, whereas the rule of law carries with it not only great moral persuasiveness but also, rightly or wrongly, a sense of objectivity. Procedural justice could be achieved in any legal or political system. After all, it can hardly be argued that fairness and justice are alien to any culture or legal system. Stripped of its philosophical overtones, the rule of law is ultimately what a 
reasonable person would regard as fair and just. Moreover, economic development is the primary concern of many developing economies in Asia, and the rule of law has been considered to be an essential condition for economic growth. Hence, the rule of law, as opposed to the more controversial notions of human rights and democracy, may prove to be a more constructive and significant discourse in this part of the world.

\section{One Country, Two Systems}

Hong Kong is a small territory of about $1,000 \mathrm{sq} \mathrm{km}$ at the southern tip of China. It has been under British rule since the mid- $19^{\text {th }}$ century, and, like all British colonies, a common law system was transplanted to this community. It has a population of about 7 million, and by 1990s, it has emerged as one of the major international financial centres in the world. ${ }^{13}$

Pursuant to the Sino-British Joint Declaration 1984, China resumed the exercise of sovereignty over Hong Kong from 1 July 1997 under the constitutional model of "one country, two systems". Under this model, Hong Kong enjoys a high degree of autonomy with its own executive, legislative and independent judicial powers, including that of final adjudication. The previous legal, social, and capitalist economic system is preserved and socialist policies do not apply to Hong Kong. The common law system is preserved. All laws previously in force are maintained, saved to the extent that they are inconsistent with the Basic Law, the constitution of the Hong Kong Special Administrative Region ('HKSAR') that implements the Joint Declaration. National laws do not apply to the HKSAR, except those specifically extended to Hong Kong. Such national laws are confined to those relating to defence and foreign affairs and matters outside the limits of the autonomy of the HKSAR. Hong Kong has its own Legislature and its own Court of Final Appeal, the latter of which comprises the Chief Justice, 3 Permanent Judges and 1 non-Permanent Overseas Judge drawn from a panel of distinguished judges from the common law countries. ${ }^{14}$ It even

\footnotetext{
${ }^{13}$ Its GDP per capita in 2014 is US\$40,169, which surpassed many developed economies in the western world: World Bank 2014: https://en.wikipedia.org/wiki/List_of_countries_by_GDP_(nominal)_per_capita.

${ }^{14}$ In all substantive appeals, the Court of Final Appeal has always included an overseas judge. Hong Kong is privileged to have the service of many leading distinguished overseas judges, including, from Australia, Sir Anthony Mason, Murray Gleeson, Justice James Spigelman and Jusice William Gummow, from England, Lord
} 
maintains its own currency, its own immigration border and administers its own immigration law. It also enjoys wide delegated powers to conduct international negotiations and to conclude international treaties, notably those relating to economic affairs, albeit under the name Hong Kong, China. A list of fundamental rights are protected by the Basic Law, which further provides that the provisions of the International Covenant on Civil and Political Rights, the International Covenant on Economic, Social and Cultural Rights, and International Labour Conventions as applied to Hong Kong shall remain in force and shall be implemented through the laws of the HKSAR. The Court of Final Appeal has held that these rights shall not be restricted unless the restrictions are prescribed by law and satisfied the tests of rationality and proportionality. ${ }^{15}$

In respect of the political system, the Legislative Council, as at 2015, comprises 70 members, half of whom are returned by direct geographical elections on the basis of adult universal suffrage, and the remaining half of whom are returned by a contrived system of functional constituencies which largely represent business and professional interests. Under the Basic Law, the ultimate aim is to have an election of all members of the Legislative Council by universal suffrage. The Chief Executive is currently elected by an Election Committee, which comprised 1,200 members, who are themselves returned by a similar system of functional constituencies. The Basic Law provides that the ultimate aim is the selection of the Chief Executive by universal suffrage upon nomination by a broadly representative nominating committee in accordance with democratic procedures.

Across the border, which is only $43 \mathrm{~km}$ away, lies a vastly different system. At the apex of that system is the National People's Congress, which exercises legislative, executive and judicial powers, and when it is not in session, the powers are vested in its Standing Committee. Separation of powers is rejected, and in its place is the central leadership of the Communist Party. In this unitary system, the Government and the Communist Party are inextricably

Hoffmann, Lord Millett, Lord Neuberger, Lord Walker, Lord Collins, Lord Clarke, Lord Phillips, and from New Zealand, Sir Thomas Munro Gault. It is unusual for a local court to have such a distinguished panel of international judges, and this international composition has significantly enriched the jurisprudence of the Court of Final Appeal.

${ }^{15}$ Leung Kwok Hung v HKSAR (2005) 8 HKCFAR 229. 
interwoven. The President enjoys immense and virtually unchecked powers, and is assisted by the Political Politburo. Leadership succession is done in the most opaque manner. Its legal system is socialist in origin, civil law in structure, and increasingly influenced by the common law system. There is no independent judiciary as generally understood in the western world, but there is an increasing trend of moving towards professionalism in the judiciary. The constitution is not actionable in courts, and the judiciary is supervised by the Procuratorate. The Public Security Bureau, the Procuratorate, and the Judiciary form a "three-horse carriage". Since the adoption of the opening- up policy in the 1980s, China has embarked on ambitious modernisation initiatives and has made remarkable progress economically. By 2014, she has emerged as the second largest global economy in the world. Despite her economic success, the rise to power of President Xi Jinping is marked by widespread suppression of dissidents. Stability is regarded as the bedrock for its economic progress, and is maintained at all costs and sometimes at the expense of civil and political rights. The rule of law is thus considered essential to build a moderately prosperous society, to rejuvenate the nation, to comprehensively deepen reforms, to perfect and develop socialism with Chinese characteristics and to enhance the Party's governance capability. ${ }^{16}$

While there is nothing new about having more than one system within a country, the gap between the two systems in the case of Hong Kong and China is probably unprecedented. On one side of the border is a western liberalized common law system that holds onto the belief of the primacy of individual liberty and freedoms, that is deeply ingrained in the doctrine of separation of powers, that is characterised by an independent judiciary, an efficient civil service that is largely free from corruption, and a free market economy with thriving economic success. On the other side of the border is a centralised socialist system that prides itself on Chinese characteristics, emphasizes party leadership and control, rejects separation of powers, believes in collective good as opposed to individual rights, and has galvanized a huge amount of wealth within a very short span of time, resulting in a huge gap between the rich and the poor, and the absence of an infrastructure and value system to

\footnotetext{
${ }^{16}$ The Communique of the $4^{\text {th }}$ Plenary Session of the $18^{\text {th }}$ CPC Central Committee, Oct 2014: https://chinacopyrightandmedia.wordpress.com/2014/10/23/official-central-committee-communique-on-4thplenum/.
} 
support such a huge, rapidly developing economy, which contributes to massive corruption at all levels of government.

The two systems are not isolated from one another. Far from it, indeed. Socially, the border between the two jurisdictions is one of the busiest in the world. Economically, Hong Kong has benefited immensely from the opening up of China, but is also increasingly dependent on the economy in China. Legally, the power of final interpretation of the Basic Law is vested in the Standing Committee of the National People's Congress. Politically, apart from defence and foreign affairs, any democratic reform could only be initiated with the consent of the Central Government.

\section{Different Perceptions of the Rule of Law in Hong Kong and China}

\section{(1) Rule of Law in Hong Kong}

The above description of the rule of law in Section III applies generally to Hong Kong. There is a general respect for the law, both by the Government and the population. The rule of law is widely accepted to be the foundation of the economic success of Hong Kong. The Basic Law is enforced by the courts, which have rigorously upheld fundamental protection for human rights. There is an independent and impartial judiciary and effective access to the courts to obtain timely remedy. The judiciary is held in high respect and the independence of the judiciary is rigorously protected. A Bill of Rights was introduced in 1990, and the Basic Law, which contains a list of fundamental rights and came into force on 1 July 1997, was vigorously enforced. ${ }^{17}$ The

\footnotetext{
${ }^{17}$ Paul Shieh SC, Chairman of the Hong Kong Bar, pointed out that Hong Kong has a thriving public law scene, citing some of the leading public law cases in support. They include HKSAR v Ng Kung Siu (1999) 2 HKCFAR 442 (constitutionality of a statute which banned flag burning), Secretary for Security v Sakthevel Prabaka (2004) 7 HKCFAR 187 (fairness of the system of screening of torture claimants), Koo Sze Yiu $v$ Chief Executive of the HKSAR (2006) 9 HKCFAR 441 (constitutionality of a statute which authorized the Chief Executive to order interception and disclosure of telecommunications), Leung $v$ Secretary for Justice [2005] 3 HKLRD 657 (constitutionality of differential age of consent between heterosexual and homosexual buggery), $W v$ Registrar of Marriage (2013) 16 HKCFAR 112 (constitutionality of a law which in effect prohibited transgender persons from marrying someone who is of the same biological sex), and Kong Yunming $v$ Director of Social Welfare (2013) 16 HKCFAR 950 (constitutionality of a statute which infringed upon the right to social welfare for newly arrived immigrants from Mainland China). To this list one can further add Cheng v Tse Wai Chun (2000) 3 HKCFAR 339 (the defence of fair comment to defamation is not defeated by malice), HKSAR $v$ Hung Chan wa (constitutionality of reverse onus provision), and Ubamaka v Secretary for Security (2012) 15 HKCFAR 743 (reservation to ICCPR ineffective to exclude torture). See Paul Shieh SC, "The role of the advocate in protecting
} 
Government and the judiciary are sensitive to any matter pertaining to the rule of law. The Chief Justice, in a recent speech, described the rule of law as follows: ${ }^{18}$

"For me, the rule of law encapsulates two important but related concepts:- first, there must exist laws which respect the dignity, rights and liberties of the individual in any society and secondly, there must exist an independent institution which enforces rights, liberties and freedoms both in letter and, more important, in spirit."

\section{(2) Rule of Law in China: the $4^{\text {th }}$ Plenum}

Since her adoption of the opening up policy in 1978, China has started to rebuild a socialist legal system with Chinese characteristics. Her slogan for the rule of law is "let there be law, let law be followed, and let law be enforced”(有法可依, 有法必依, 違法必究). In 1997, in the $15^{\text {th }}$ National Congress of the Communist Party of China, it was decided that "the rule of law" be adopted as a basic strategy and the "building of a socialist country under the rule of law" as an important goal for socialist modernisation. In 1999, the phrase "exercises the rule of law, building a socialist country governed according to law" was written into the constitution. More than three decades have since passed, and it is impressive that China has largely achieved the first aim of "let there be law". There is a huge amount of legislations covering almost all areas of human activities. However, much remain to be said about the compliance and the enforcement of law. Abuse of powers is still prevalent; so are corruption and the lack of effective enforcement of law. Among other problems, the absence of an independent, impartial and competent judiciary stands out conspicuously. Until recently, there has been an uneasy ambiguity, even at the rhetorical level, as to the extent the Communist Party is subject to the rule of law.

human rights and the rule of law", a paper presented at the World Bar Conference 2014, Queenstown, New Zealand.

${ }^{18}$ Geoffrey Ma CJ, "Strength and Fragility in Tandem: The Rule of Law in Hong Kong", Annual International Rule of Law Lecture 2015, the Bar Council of England and Wales. 
In this sense, it is encouraging to see that the rule of law was made, for the first time, the central theme of the $4^{\text {th }}$ Plenum of the $18^{\text {th }}$ Central Committee of the Communist Party of China (CPC) held in October 2014. Indeed, in 2012, the new leadership of the CPC already envisaged that by 2020, "the rule of law should be fully implemented as a basic strategy, a law-based government should be basically functional, judicial credibility should be steadily enhanced, and human rights should be fully respected and protected." ${ }^{19}$ The communique of the $4^{\text {th }}$ Plenum highlights a number of priority areas: (1) to strengthen the implementation of the Constitution and the primacy of legislation as the legal basis for governance and to continue improving the quality of law and lawmaking process; (2) to enhance the implementation of the law; (3) to improve the judicial system through establishing a circuit court system, enhancing the impartiality of the judiciary, investigating any leading cadres' interference with judicial activities, raising judicial standards through quality recruitment, strengthening judicial guarantees for the protection of human rights and judicial powers in enforcement; (4) to raise public awareness of the rule of law; (5) to enhance the transparency and openness in government affairs and management; and (6) to strengthen the mechanism and consciousness of the rule of law within the Party. In short, all these measures are to enhance the building of a law-based society, and above all, to strengthen and consolidate Party leadership as "the most essential characteristic of Socialism with Chinese characteristics and the most fundamental guarantee for Socialist rule of law."

A few observations could be made. First, the communique is, as usual, full of rhetoric and vague visionary statements. It remains to be seen how far it is implemented. However, even at the rhetorical level, it is noteworthy that there are a lot of common grounds with the western notion of the rule of law, save for the emphasis on party leadership. As far as the Communist Party is concerned, the communique accepts that the Party has to abide by law and the constitution. Secondly, while critics are quick to point out that the only real message is the overarching principle of strengthening Party leadership and that the harsh reality of Xi Jinping's rise to power remains that of persistent suppression of dissidents and their lawyers as well as fragrant violations of fundamental rights, it is probably unfair to dismiss the document as pure

\footnotetext{
${ }^{19}$ Wang Cong, "Xinhua Insight: CPC convenes first plenum on 'rule of Law' in reform, anti-graft drive', 20 Oct 2014: http://www.china.org.cn/china/fourth_plenary_session/2014-10/20/content_33815182.htm.
} 
propaganda or a worthless sophistry. The message of moving towards a lawbased society is still loud and clear. However, the recent arrest and detention of over $\mathbf{2 0 0}$ human rights lawyers across the country, in some cases even their family members are detained, is certainly disturbing and warrants the concern of the global legal community. Thirdly, the emphasis on the rule of law is functional and pragmatic. It is a means to deepen economic reforms and further economic development. It is realised that many problems that China faces, such as "overcapacity, real estate bubbles, risks of local government debts and shadow banks, restricted growth in non-public sectors and insufficient innovation", ${ }^{20}$ excessive administrative interference, unfair competition and unfair participation of state/local government organs in the market, and above all, the prevalence of corruption at all levels of government, have all of their roots in the absence of the rule of law.

Fourthly, there are concrete measures to improve the judicial system. As Professor Jerome Cohen pointed out, while "the party's most powerful leaders do not want to subject their own decisions to the strictures of law, ... they plainly want to end the local protectionism, politics, corruption, backdoor contacts and other adverse influences that distort mundane judicial decisionmaking, fuelling popular distrust of the courts and the entire legal system."21 Yet it is difficult to maintain a parallel system to have an independent judiciary in civil and economic matters, but a compliant judiciary in constitutional or issues that matter to the Government. Freeing the judiciary from local influences has been a constant theme in recent years. Apart from the establishment of circuit courts, there is also budgetary reform so that the budget of local judiciary is no longer dependent on the local government. However, without a protected budget, the price for central fiscal provision is that while the judiciary is free from one master, it is now subject to an even tighter control by another master, the Central Government.

Fifthly, the parallel system of party discipline and the judicial system in dealing with corruption, especially that took place at a senior level, remains an uneasy feature of the Chinese legal system. On the one hand, it means that the judicial system is not powerful enough to deal with high-level corruption. On

\footnotetext{
${ }^{20}$ Wang Cong, ibid.

${ }^{21}$ Jerome A Cohen, "China's socialist rule of law still offers real hope of improvements to legal system, South China Morning Post, 19 June 2015.
} 
the other hand, the extra-judicial mechanism that lies entirely in the hands of the Party does not sit well with the notion of the rule of law or open justice. ${ }^{22}$

Hence, even with the most benign interpretation of the communique, there remains a huge gap in the understanding and the practice of the rule of law between the two systems in Hong Kong and China. The level of discussions on the rule of law in China still stays largely at the level of the existence of laws and at most, at procedural justice. There is little discussion at the official level about the core values of the rule of law or proportionality of measures that curb civil rights and liberties. There are measures trying to strengthen the judiciary, but beyond that, there is not much about implementation or enforcement of the law. Hence, what the law says could be one thing; what the actual practice could be quite another. The contrast is most profound when the two systems interact with one another. This happens at the interpretation of the Basic Law, which is both the constitution of Hong Kong and a piece of national law of China.

\section{(3)}

The Gap: Judicial or Legislative Interpretation?

Under Article 158 of the Basic Law, the power of final interpretation of the Basic Law is vested in the Standing Committee of the National People's Congress ('NPCSC'), which is a political organ. The Hong Kong courts have the power of interpreting the Basic Law, but the power of the Court of Final Appeal to do so is restrained. It has a duty to refer a question of interpretation to the NPCSC if, in rendering its final judgment, it is necessary to interpret a provision of the Basic Law that falls within the areas of defence and foreign affairs or matters outside the autonomy of the HKSAR.

Under the common law system, interpretation of the law is a judicial function. Only the courts have the power to make authoritative interpretation of the law.

\footnotetext{
${ }^{22}$ It is true that the corrupted officials will be transferred to the judicial system for trial at a later stage, but it gives the public an impression that the outcome of the trial is already sealed before the trial. Indeed, none of the senior officials investigated by the Party and transferred to the judiciary managed to escape convictions. See also the excellent analysis of Fu Hualing, "Wielding the Sword: President Xi's New Anti-Corruption Campaign" in Susan Rose-Ackerman and Paul Felipe Lagunes (eds), Greed, Corruption, and the Modern State (EE, 2015):

http://papers.ssrn.com/sol3/papers.cfm?abstract_id=2492407.
} 
The interpretation is a public process, under which the court will only make a statutory interpretation in the course of judicial adjudication, and will reach its decision only after hearing full arguments from the parties. There are established principles governing the approach to interpretation and the materials that the court could refer to in the interpretation process, and the interpretation will be fully justified with detailed reasoning in the judgment. If the final appellate court makes a decision that is politically or socially unacceptable, the operation of the doctrine of separation of powers means that the Legislature can overturn the court decision by amending the relevant law, and if the interpretation involves a constitutional provision, by amending the relevant constitutional provision if necessary.

In contrast, under the socialist system of law in China, the power to make authoritative pronouncement on the interpretation of law is vested in different institutions, including some political institutions. The judiciary has power to make an interpretation of law outside judicial adjudication. The NPCSC has power to make authoritative pronouncement on statutory interpretation and does exercise this power from time to time. The interpretation is a legislative rather than a judicial process. It is not an open process, and no reason is provided for in the interpretation. The interpretation can fill the gap in existing legislation or elaborate and expand the scope of existing legislation. In this sense, the distinction between interpretation and amendment of law is rather blurred. NPCSC interpretation of the law is justified on the ground that it is the most efficient and effective means of ensuring consistency of legal interpretation given an uneven judicial quality in the country, especially at the initial period of opening up of the country in the late 1970s. It is probably also a means to ensure the leadership of the Party, which could then exert strong control on the direction of legal development.

\section{(4) The Tension: Two Instances}

In Ng Ka Ling v Director of Immigration, ${ }^{23}$ the issue was whether a requirement to produce a certificate of entitlement in order to claim a right of abode in Hong Kong was consistent with Art 24 of the Basic Law. This case involved a

\footnotetext{
${ }^{23}$ (1999) 2 HKCFAR 4.
} 
claim of about 5,000 potential claimants. They were children born in Mainland China to Hong Kong Permanent Residents before the change of sovereignty over Hong Kong in 1997. Under the pre-handover law, these children did not have any right of abode in Hong Kong, but Art 24 of the Basic Law, which defined the persons who have a right of abode in Hong Kong, is wide enough to include these children. ${ }^{24}$ As there were a large number of claimants who came forward within a short period of time shortly after the changeover, the Provisional Legislative Council adopted an emergency legislative amendment to require these claimants to produce in support of their claim a certificate of entitlement, which could only be applied outside Hong Kong and be issued with the approval of the security bureau of the Mainland. In an elaborated judgment, the Court of Final Appeal reviewed the historical development of the concept of right of abode, highlighted that the right of abode was a fundamental right of Hong Kong Permanent Resident and that such right should receive a liberal interpretation and subject only to restrictions that were proportionate, and held that it was a disproportionate restriction of the right of abode when this right was effectively determined by the Security Bureau of the Mainland through a refusal to grant an exit permit under the certificate of entitlement scheme. In adopting a purposive approach of interpretation of the Basic Law, the Court qualified that the purpose and intent of the Basic Law should primarily be ascertained from the language of the constitution, as it was not the role of the Court to re-write the constitution.

While the judgment of the Court of Final Appeal was generally hailed as a classical liberal judgment, the HKSAR Government found the judgment disturbing and suggested that about 1.6 million children would acquire a right of abode in Hong Kong overnight under this judgment. ${ }^{25}$ Thus, it sought to request the NPCSC to give an interpretation of the Basic Law with a view to overruling the judgment of the Court. This decision, as well as the subsequent interpretation by the NPCSC, was subject to severe criticisms notably by the legal profession. It was argued that the independence of the judiciary and the integrity of the Hong Kong legal system would be undermined if a political organ, acting in a most opaque manner, can overrule a carefully reasoned

\footnotetext{
${ }^{24}$ Art 24(2)(3) of the Basic Law provides that "persons of Chinese nationality born outside Hong Kong of those residents [who are HKPR]" are permanent residents of the HKSAR.

${ }^{25}$ This figure was generally regarded as highly inflated.
} 
judgment of the Court of Final Appeal, without having to provide any reason. If the Government found the judgment of the Court of Final Appeal unacceptable, the proper approach was to amend the Basic Law. Legislature is not omnipotent and could not contemplate all eventualities in the future. The problem of a large number of children born in the Mainland was not a foreseeable problem in 1990 when the Basic Law was promulgated. Thus, with changing social circumstances, the only proper approach is to amend the Basic Law. Amendment is a formal process and subject to the debates and discussions inherent in the process. In contrast, the decision of the NPCSC is made behind closed doors, with no established safeguards or procedures, and with no public participation.

Notwithstanding these powerful arguments, the NPCSC decided to make an interpretation, which is in a form of an edict with no reasons or justifications. It merely stated in a categorical manner that the intent of the Basic Law was not to confer a right of abode on these children, and in this way reversed the judgment of the Court of Final Appeal. In ascertaining the intent of the Basic Law, it merely referred to a report of a Preparatory Committee, which was set up in 1996 to prepare for the transition of Hong Kong to become a special administrative region of China.

The interpretation has made considerably adverse impact on the independence of the judiciary in Hong Kong. It appears that the NPCSC can at any time issue an interpretation and thus "reverse" the judgment of a Hong Kong court or render the judgment meaningless. It may also suggest that a Hong Kong judge would have to look over his shoulder to ensure that his judgment would not be in conflict with what the NPCSC would accept. If so, this would be a fatal blow to the accepted notion of the rule of law. In a subsequent judgment, ${ }^{26}$ the Court of Final Appeal held that the NPCSC interpretation is legislative in nature, and that the court will and shall not take into account how the NPCSC would respond to its interpretation in interpreting the Basic Law, just like the court will not take into account how the Legislative

\footnotetext{
${ }^{26}$ Director of Immigration v Chong Fung Yuen (2001) 4 HKCFAR 211. For a more detailed discussion, see Johannes Chan, "Hong Kong Constitutional Journey 1997-2011", in Albert Chen et al (eds), Comparative Asian Constitution (Cambridge University Press, 2014), pp 169-193.
} 
Council would respond to its judgment in discharging its judicial duties. In interpreting the Basic Law, the Court will continue to apply the common law principles. The Legislature, and in this regard, the NPCSC, has full power to respond to the judgments of the courts once they are pronounced, as this is in accord with the doctrine of separation of powers, but their response has no place in the judicial interpretation of the law and in the discharge of its judicial functions. Insofar as the materials to be taken into account, the Court held that while it was permissible to consider extrinsic materials such as the Joint Declaration and the travaux preparatoires of the Basic Law, it would be most exceptional for the court to take into account a report made by a committee which has no power to interpret the Basic Law and which report was made only six years after the Basic Law has been promulgated.

Another aspect of the decision in $\mathrm{Ng} \mathrm{Ka}$ Ling $v$ Director of Immigration is whether the Standing Committee of the National People's Congress ('NPCSC') has the power to appoint a Provisional Legislative Council in Hong Kong upon the change of sovereignty when there is no provision for such a Provisional Legislative Council in the Basic Law. The Court of Final Appeal held that it has jurisdiction to review the compatibility of a resolution of the NPCSC with the Basic Law. Its reasoning is as follows: (1) Hong Kong is vested with independent judicial power; (2) in exercising their judicial power under the Basic Law, the courts have a duty to enforce and interpret that law, including a duty to declare any legislation unconstitutional if such legislation is found to be inconsistent with the Basic Law; (3) this jurisdiction is derived from the Chinese Constitution under which authority the Basic Law is enacted; (4) the Basic Law is a piece of national law which binds PRC organs; (5) If the act of a PRC organ is inconsistent with the Basic Law, it is for the courts to determine questions of inconsistency and invalidity of that act so long as the act falls within the high degree of autonomy of Hong Kong; (6) therefore, the Hong Kong courts have jurisdiction to determine whether an act of the NPC or its Standing Committee is inconsistent with the Basic Law.

The assumption of constitutional jurisdiction by the Court of Final Appeal over the acts of the Central Government, a power which even the People's Supreme Court of the Mainland does not enjoy, was unacceptable to the Central 
Government. After considerable pressure, the Court of Final Appeal made a clarification which is highly ambiguous: ${ }^{27}$

“The Court's judgment on 29 January 1999 did not question the authority of the Standing Committee to make an interpretation under art 158 which would have to be followed by the courts of the Region. The Court accepts that it cannot question that authority. Nor did the Court's judgment question, and the Court accepts that it cannot question, the authority of the National People's Congress or the Standing Committee to do any act which is in accordance with the provisions of the Basic Law and the procedure therein." (italics supplied)

While it remains ambivalent whether the Hong Kong courts have jurisdiction over the legality of an act or decision of the NPC or the NPCSC when the act or decision is not in accordance with the Basic Law, a more fundamental question is whether the NPC or the NPCSC is bound by the legislation that it passes, in this case the Basic Law. There is little comfort to say that the NPC and the NPCSC are bound by the Basic Law and at the same time the Basic Law could be interpreted to mean what the NPC or the NPCSC would say with no other means of enforcement. Here lies the difficulty of the concept of the rule of law in China: the state is law-abiding, but only when the law means what the state wants it to mean!

The Court of Final Appeal has since restored public confidence in its independence by its reaffirmation that, in the interpretation of the Basic Law, it is to be guided by the common law principles only. The explanation of the NPCSC interpretation being legislative in nature provides a useful model to protect the integrity of the judicial process. However, this model may not work in the context of judicial reference under Art 158 of the Basic Law. It may be recalled that the Court has a duty to refer a question to the NPCSC for interpretation if it is necessary to interpret a provision of the Basic Law that falls in the areas of defence and foreign affairs and matters outside the autonomy of the HKSAR. The referral has to be made before the Court of Final Appeal renders its final judgment. This arrangement was said to be modeled

\footnotetext{
${ }^{27} \mathrm{Ng}$ Ka Ling v Director of Immigration (No 2) [1999] 1 HKLRD 577, at 578. The statement did not explain the position if the act of the NPC or its Standing Committee is not in accordance with the Basic Law or the procedure there.
} 
after that of the European Community ("EC"), under which the final appellate court of a member state has a duty to refer a question of the EC law to the European Court of Justice for interpretation if the interpretation is necessary for the final disposal of the case before the domestic court, and the interpretation of the European Court of Justice is binding on the domestic court. This comparison is however superficial. First, the European Court of Justice is a formal court staffed by judges who are members of the judiciary or who are qualified to serve on the judiciary of the member states. In contrast, the NPCSC is a political organ. Secondly, under the EC system, the case was partially transferred to the European Court of Justice, which means that the parties before the hearing in the domestic court have the opportunity to appear before the European Court of Justice to address the court before it renders its interpretation. There are due process guarantees. In contrast, everything before the NPCSC is confidential. It is not even known when the question would be considered by the NPCSC or what materials are placed before the NPCSC for its consideration, let alone a right to appear before the NPCSC.

Thus, the explanation that the NPCSC interpretation is legislative in nature does not address these due process issues. If it were legislative in nature, it would be wrong for the law to be changed in the middle of a hearing, as it would tantamount to applying the law with retrospective effect to the parties immediate to the proceedings. Yet if it were not legislative in character, the due process issues remain unanswered.

The first judicial referral case arose ten years after the decision in $\mathrm{Ng} \mathrm{Ka}$ Ling. In F G Hemisphere Associates LLC v Democratic Republic of Congo, ${ }^{28}$ the issue was whether a sovereign state could claim absolute immunity in all circumstances in a Hong Kong court ("absolute immunity"), or whether the immunity ceased to apply when the state was involved in purely commercial transactions ("relative immunity"). In that case, the applicant tried to enforce in Hong Kong an arbitral award against the Congo Government by asking the Hong Kong court to direct a PRC state own enterprise to satisfy the arbitral award with monies the PRC enterprise owed to the Congo Government under a separate mining agreement. The Congo Government pleaded state immunity

\footnotetext{
${ }^{28}$ (2011) 14 HKCFAR 95.
} 
before the Hong Kong court. The common law adopted the doctrine of relative immunity, whereas absolute immunity is the foreign policy of China, and this policy is of particular significance to China in relation to its strategic development in Africa. Should Hong Kong continue to uphold the common law position, or should she follow the national policy? The Secretary for Justice of the HKSAR intervened in the proceedings, and the PRC Foreign Ministry put forward its concern to the court through the Secretary for Justice. It was argued that the country should speak with one voice in relation to state immunity, and any common law principle that is contrary to the PRC foreign policy is inconsistent with the Basic Law. The Court of First Instance upheld the claim for immunity on the ground that the relevant transaction was in any event not commercial in nature. Hence it was unnecessary to decide whether Hong Kong law should adopt the position of absolute immunity or relative immunity. On appeal, the Court of Appeal held that the relevant transaction was commercial in nature, and rejected the claim for immunity as such claim was inconsistent with the common law principle. On further appeal, the Secretary for Justice urged the Court of Final Appeal to refer a question to the NPCSC for interpretation.

The Court of Final Appeal declined the invitation to rule on the question of referral in abstract. Instead, it directed that full arguments on the merits of the case be made. After hearing full arguments from all concerned parties, the Court, by a majority of 3 to 2 , decided that state immunity falls within the area of foreign affairs and that it has a duty to refer the relevant provisions of the Basic Law to the NPCSC for interpretation. The Court, also after consulting the parties, drafted and referred to the NPCSC four questions for interpretation. It also delivered a provisional judgment on the substantive merits, and sent the judgment alongside the questions for interpretation to the NPCSC for its consideration. The judgment consisted of two strong dissenting judgments, which held that (1) this was a case of an enforcement of arbitral award; China as a sovereign was not involved in the proceedings as such and there was no issue of sovereignty or foreign affairs; (2) the matter was to be governed by the common law; (3) the relevant transaction entered into by the Congo Government was purely commercial in nature; (4) whatever be the position regarding state immunity, by submitting itself to arbitration the Congo Government has waived its immunity. Although there might be a distinction 
between waiver to jurisdiction and waiver to enforcement, this distinction operates in an unfair manner and should not be adopted.

Not surprisingly, the NPCSC in its subsequent interpretation stated that any common law principle of relative immunity did not survive the changeover and was hence deemed to be overruled by the Basic Law. In giving its interpretation, the NPCSC did confine itself to the four questions posed by the Court of Final Appeal. Thus, the procedural side is of significance. China, through the Secretary for Justice, participated at the hearing and submitted its view to the court in the same manner as any other litigants. The questions that need interpretation were prepared by the Court of Final Appeal, and these questions defined the scope of interpretation. In deciding to make a judicial referral, the Court of Final Appeal did not merely certify the questions for interpretation but also gave its own answers to these questions. The provisional judgment is an attempt to present the common law view for consideration by the NPCSC. The provisional judgment was reached after hearing the arguments of all the relevant parties to the proceedings. By laying down these procedures, the Court tried to address the problem of the absence of due process before the NPCSC and to set up a convention to minimize the arbitrariness of the interpretation of the NPCSC. Although the Court of Final Appeal has no power to bind the NPCSC, the NPCSC seems to have accepted that it should confine itself to the questions posed by the Court of Final Appeal.

\section{(5) Narrowing the Gap?}

These two cases highlight very different perceptions of the rule of law between a common law system in Hong Kong and a socialist/civil law system in Mainland China. It is not possible to completely eliminate the gap given the fundamental difference on the role of law in the two systems. The interaction between the two systems exposes some of the problems of the rule of law as proclaimed in China. Among other things, the strong reaction in Hong Kong towards the NPCSC interpretation does give rise to renewed concern of the efficacy of legislative interpretation. Such kind of political edict may be justified when China is still at an early stage of rebuilding the legal system after

a complete breakdown of law and order during the Cultural Revolution. Yet, 
almost 40 years have since passed. When she vows to build a law-abiding state, the continued adoption of legislative interpretation is at odds with the rule of law. At the very least, it blurs the distinction between an interpretation and an amendment of the law, and allows the state organ to interpret the law to suit its purposes. This is far from what the rule of law should mean.

\section{The Rule of Law and Democracy}

If the rule of law presupposes the respect for certain fundamental values, what happens if the law violates these fundamental values? The example of the law authorizing racial cleansing is well known. How about law denouncing democracy in a democratic state? Is such law still "law"? Should one obey such law? If one were free to disobey such law, would this be an affront to the rule of law? The rule of law was called into question in the recent Umbrella Movement in Hong Kong. ${ }^{29}$ It may be recalled that the ultimate aim of the Basic Law is to select the Chief Executive of Hong Kong by universal suffrage upon nomination by a broadly representative nominating committee in accordance with democratic procedure. ${ }^{30}$ The pace of introducing direct election of the Chief Executive is to be determined by the NPCSC, which decided in 2007 that the Chief Executive in 2017 may be returned by universal suffrage. In 2014, however, the NPCSC decided to mandate a contrived nomination procedure which effectively enables only Beijing-approved candidates to get through the nomination process. This decision provoked strong reactions in Hong Kong, and protesters occupied the main thoroughfares in Hong Kong for 79 days with a view to putting pressure on the Central Government to withdraw its decision. The movement got its name when protestors used umbrellas to protect themselves against police spray of tear gas. The occupation was against the law and as it was prolonged, it caused considerable inconvenience to the public. It became highly divisive, drawing many supporters as well as opposition to the occupation. The movement is justified as a form of civil disobedience, and the question arises as to whether civil disobedience is against the rule of law.

\footnotetext{
${ }^{29}$ For a discussion on the Umbrella Movement, see Johannes Chan, "The Hong Kong Umbrella Movement", (2014) 103(6) The Round Table: The Commonwealth Journal of International Affairs 571-580.

${ }^{30}$ Art 45 of the Basic Law.
} 
Civil disobedience can be traced back to 1848 when Henry Thoreau refused to pay taxes as an act of protest against slavery and the Mexican-American War. ${ }^{31}$ It is one of the means where people rebel against what they perceive to be unjust law. The best known form of civil disobedience is the nonviolent resistance movement led by Gandhi during the Indian independence movement. This has since been followed in many other places, such as Czechoslovakia's Velvet Revolution, the campaign against apartheid in South Africa, the American Civil Rights Movement, the Singing Revolution in the Baltic Countries that led to the collapse of the Soviet Union, the Rose Revolution in Georgia in 2003, the Orange Revolution in Ukraine in 2004, and possibly the Arab Spring movement in the Arabic World in 2011-2013, as well as the Sunflower Movement in Taiwan in 2014. Broadly, civil disobedience shares some common characteristics: (1) it is unlawful; (2) the unlawful act is publicly announced; (3) it is non-violent; (4) it is done in order to demonstrate the injustice of the law with a view to changing the law or policy, and (5) the perpetrators are prepared to accept the legal consequences of their unlawful act. It is not a defence to prosecution, although jurists differ in their approach to civil disobedience.

Professor Ronald Dworkin accepts that civil disobedience could be morally justified: ${ }^{32}$

"In a democracy, or at least a democracy that in principle respects individual rights, each citizen has a general moral duty to obey all the laws, even though he would like some of them changed. He owes that duty to his fellow citizens, who obey laws that they do not like, to his benefit. But this general duty cannot be an absolute duty, because even a society that is in principle just may produce unjust laws and policies, and a man has duties other than his duties to the state. A man must honour his duties to his God and to his conscience, and if these conflict with his duty to the state, then he is entitled, in the end, to do what he judges to be right. If he decides that he must break the law, however, then he must submit to the judgment and punishment that the state

\footnotetext{
${ }^{31} \mathrm{H}$ Thoreau, Civil Disobedience (1866). Indeed, in Greek mythology, when Antigone defied the King of Thebes from stopping her to give her brother a proper burial, she gave a powerful speech that she knew the law but has to obey her conscience; this is one of the earliest depictions of civil disobedience: see Sophocles' Antigone (Harvard University Press, 1912).

${ }^{32}$ R Dworkin, Taking Rights Seriously (Harvard University Press, 1977), at pp 186-187.
} 
imposes, in recognition of the fact that his duty to his fellow citizens was overwhelmed but not extinguished by his religious or moral obligations."

In Canada, Wood J regarded civil disobedience as an affront to the rule of law. The learned judge observed: "...by seeking to change the law by deliberately disobeying it you threaten the continued existence of the very instrument, indeed the only instrument through which you may eventually achieve the end you seek. Such conduct is not only illegal, it is completely self-defeating." ${ }^{33}$ In contrast, in England, Lord Hoffmann adopted a more sympathetic view and laid down some limits for civil disobedience: "Civil Disobedience on conscientious grounds has a long and honourable history in this country. People who break the law to affirm their belief in the injustice of a law or government action are sometimes vindicated by history. The suffragettes are an example which comes immediately to mind. It is the mark of a civilised community that it can accommodate protests and demonstrations of this kind. But there are conventions which are generally accepted by the law-breakers on one side and the law-enforcers on the other. The protesters behave with a sense of proportion and do not cause excessive damage or inconvenience. And they vouch the sincerity of their beliefs by accepting the penalties imposed by the law. ${ }^{\prime 34}$ The litmus test is that it has to be kept in proportion and does not cause excessive damage or public inconvenience. Since the legitimacy of civil disobedience rests on public support, it will lose its legitimacy if it has caused excessive damage or public inconvenience and lost public support. This is the situation regarding the Umbrella Movement in Hong Kong. The Movement initially attracted considerable public support, but when the occupation of the main thoroughfares dragged on for over two months, it began to lose public support as it has caused a lot of inconvenience to members of the public, and this eventually led to some discontented members of the public bringing a legal action in public nuisance to bring an end to the occupation.

\footnotetext{
${ }^{33}$ Everywoman's Health Centre Society (1988) v Bridges (1989) 61 DLR $\left(4^{\text {th }}\right) 154$.

${ }^{34} R$ v Jones (Margaret) [2007] 1 AC 136, at para 89.
} 
In any event, while Lord Hoffmann accepted that civil disobedience should be tolerated up to a point, the moral justification is not a legal defence, at least when the law itself is not unjust: ${ }^{35}$

"This suggests that while the demonstrator or objector cannot be morally condemned, and may indeed be praised, for following the dictates of his conscience, it is not necessarily unjust for the State to punish him in the same way as any other person who breaks the law. It will of course be different if the law itself is unjust. The injustice of the law will carry over into its enforcement. But if the law is not otherwise unjust, as conscription is accepted in principle to be, then it does not follow that because his objection is conscientious, the State is not entitled to punish him. He has his reasons and the State, in the interests of its citizens generally, has different reasons. Both might be right."

\section{The Rule of Law and Independence of the Judiciary}

This brings us to the enforcement aspect of the rule of law. Law is a pious document unless it is enforced. In the enforcement of the law, the court stands between the people and the state. For people to trust the courts, it is essential that the courts have to be impartial and independent of the state. This is so whether it is in the common law system or civil law system. Among the three branches of governments, the judiciary is the weakest. It earns its legitimacy, not by popular ballots, but by its transparency, its rationality, its fairness and its independence. The judiciary is not there to enforce government policy. Instead, it is there to ensure that the Government does not transgress beyond what the law permits. It should be fair to the parties to the litigation, Government and citizens alike, and in discharging its judicial duties, it is accountable only to the law.

The role of the judiciary attracted grave concern in Hong Kong in 2014. In June 2014, the State Council of the PRC published a White Paper on the Practice of One Country, Two Systems, in which it described the judiciary as part of the

\footnotetext{
${ }^{35} \mathrm{Ibid}$, at para 33. It may be the case that a judge may refuse to enforce the law in the extreme circumstances that the law is blatantly unjust, such as a law authorizing racial cleansing or torture.
} 
"administration" who is expected to "co-operate" with the government and who have to be patriotic. The White Paper stated: ${ }^{36}$

'Under the policy of 'one country, two systems', all those who administrate Hong Kong, including... judges of the courts at different levels and other judicial personnel, have on their shoulders the responsibility of correctly understanding and implementing the Basic Law, of safeguarding the country's sovereignty, security and development interests, and of ensuring the long-term prosperity and stability of Hong Kong. In a word, loving the country is the basic political requirement for Hong Kong's administrators. If they are not consisted of by patriots as the mainstay or they cannot be loyal to the country and the HKSAR, the practice of 'one country, two systems' in the HKSAR will deviate from its right direction, making it difficult to uphold the country's sovereignty, security and development interests, and putting Hong Kong's stability and prosperity and the wellbeing of its people in serious jeopardy."

This statement has provoked strong responses from Hong Kong. The former Chief Justice wrote, "In Hong Kong, patriotism had been widely perceived as being 'supportive of and cooperating with' the Beijing and Hong Kong governments, and protecting their interests. But under the principle of judicial independence, judges should not be pro or anti anyone or anything. Judges were expected to be fair, impartial and faithful only to the law." ${ }^{37}$ The Chairman of the Bar is more direct: ${ }^{38}$

"A system without a truly independent judiciary and where laws are arbitrarily enforced, the judiciary and the executive 'co-operate' to ensure that laws are interpreted in a way preferred by the executive and are used to suppress persons or entitles who do not find favour with the Government. This is often dressed up as 'Rule of law', but is in fact 'Rule by Law'. 'Do things according to law' means 'do things according to our will'.... The real problem with the relevant part of the White Paper is that... judges perform judicial tasks independently. The sovereign state

\footnotetext{
${ }^{36}$ PRC White Paper on The Practice of the One Country, Two Systems Policy in the HKSAR (2014), at para 3.

37 "Judges don't need to be patriots, says former top judge Andrew Li," South China Morning Post, 15 Aug 2014 : http://www.scmp.com/news/hong-kong/article/1573867/judges-dont-need-be-patriots-andrew-li?page=all. ${ }^{38}$ Speech of the Chairman of the Hong Kong Bar Association at the Opening of the Legal Year 2015, 12 Jan 2015, paras 6, 8-9: http://www.hkba.org/whatsnew/misc/OLY\%20Speech\%202015\%20(E)\%20web.pdf.
} 
should not purport to impose any ambiguous political requirements, such as to be 'patriotic' or to 'safeguard the country's development interests.... The White Paper sends a wrong message to the people of Hong Kong and the international community as to the role of the judiciary in Hong Kong. It also shows a gap in mindset. In systems subscribing to our concept of Rule of Law, the Government does not paternalistically issue edicts for judges to perform political tasks."

The difference goes to the differently perceived roles of the judiciary. In China, the courts are part of the administration, and therefore judges are expected to be compliant and co-operative with the Government. While there is still a long way to go before the judiciary in China could become genuinely independent, the current judicial reform, notably that of enhancing open justice, raising judicial quality through training and recruitment as well as providing better remuneration package, freeing the judiciary from local protectionism through the establishment of the circuit courts and budget sources, and improving access to justice, may have far more profound impact than it is anticipated. ${ }^{39}$ As the judiciary becomes more professional, there will be demands from within to become more independent and impartial. Any professional judiciary will recognize that the reputation and legitimacy of the judiciary rests on its fairness and impartiality. To an extent, judicial independence is not inconsistent with patriotism. A judge can meet the requirement of patriotism by taking an oath of allegiance, and yet demonstrate his patriotism by "an irrevocable and undiluted commitment to the rule of law, which involves resolving disputes independently, fearlessly, honestly, fairly, and in accordance with the law, and as efficiently and openly as their capabilities and circumstances permit." ${ }^{\prime 40}$ While there are systemic hurdles that need to be overcome, the current judicial reform in China, if successfully implemented, may considerably narrow the gap of the understanding of the rule of law and the development of the rule of law in China.

\footnotetext{
${ }^{39}$ For more details of the reform, see Meng Jianzhu, “Deepening Judicial Reform”, People's Daily, 23 Nov 2013 (Meng Jianzhu is the Chairman of the Party's Political-Legal Committee): http://news.sohu.com/20131125/n390836493.shtml.

${ }^{40}$ Lord Neuberger, "The Third and Fourth Estates: Judges, Journalists and Open Justice", a speech at the Hong Kong Foreign Correspondents' Club, 26 Aug 2014, para 11:

http://www.constcourt.md/public/files/file/Publicatii/Lord_Neuberger.pdf
} 
If the judiciary is genuinely independent, it will not be surprising that it may deliver judgments that are embarrassing to the Government. The reverse is equally true that the judiciary may deliver judgments that are disappointing to the public. Sometimes there is a tendency to hail the courts as the defender of the rule of law when the courts rule against the Government, whereas it is said to be the dark day of the rule of law when the courts rule in favour of the Government. Such sentiment is both unwarranted and unhealthy. In the Umbrella Movement, when public tolerance to the prolonged occupation of public thoroughfares ran out, some applicants successfully applied for an injunction to disperse the protesters. Judges are then insinuated by the protesters or their supporters to be co-operating with the Government to oppress the democratic supporters. There were even public calls to defy the injunction orders. This may be justified if the courts, as the notorious Star Chambers were, are part of the oppressive regime, but the situation in Hong Kong is far from that. After all, in the application for an injunction order, the protesters were legally represented and had a fair hearing in court. Legal aid was made available and senior counsel was briefed. The court heard arguments on both sides and gave a reasoned judgment in granting the injunction order. ${ }^{41}$ The protesters appealed, and the appeal was refused by the Court of Appeal. To defy a court order in such a situation is to defy the very institution by which the rule of law is upheld. As Mr Justice Bokhary, a retired permanent judge of the Court of Final Appeal, observed in an interview: $:^{42}$

"It is difficult to see how disobedience of a court order would not impact the rule of law. I don't think it will deal rule of law a death blow, but it does impact on it... Sometimes in some places the law is so oppressive that anybody in opposition to the regime would come up against the oppressive law... But in a place like Hong Kong I don't think we have had that kind of situation."

\footnotetext{
${ }^{41}$ Chiu Luen Public Light Bus Company Ltd v Persons Unlawfully Occupying or Remaining on the Public Highway namely the Westbound Carriageway of Argyle Street between the Junction of Tung Choi Street and Portland Street and/or other persons hindering or preventing the passing or repassing of Argyle Street, HCA 2086/2014 (10 Nov 2014). See also Geoffrey Ma CJ, "Strength and Fragility in tandem: The Rule of Law in Hong Kong", The Bar Council of England and Wales Annual International Rule of Law Lecture 2015.

${ }^{42}$ Interview on 23 November 2014, as quoted by the Chairman of the Hong Kong Bar Association in his speech at the Opening of the Legal Year 2015, supra, at para 17.
} 


\section{Constitutional Review, the Rule of Law and Democracy}

China has a written constitution. The communique emphasizes that the country should be ruled in line with the constitution. Yet the constitution is not enforceable by the courts and its interpretation is vested in the political organ. Those who oppose constitutional review point to the risk of judicial supremacy. Is constitutional review legitimate and if so, would it politicize the judiciary? After all, it is as a result of the doctrine of separation of powers that the United Kingdom has decided not to give the power to the judiciary to strike down legislation that is found to be incompatible with the Human Rights Act, and the same applies in the case of the New Zealand Bill of Rights.

On the question of legitimacy, it is unnecessary to repeat the orthodox justification in Marbury $v$ Madison that the power of constitutional review is derived, not from Parliament sovereignty, but from the sovereignty of the people who confer sovereignty on Parliament. ${ }^{43}$ Parliamentary supremacy rests on the divine right of the majorities. While this forms the bedrock of democracy, the risk of majority dictatorship is equally well known. As Lord Hailsham of St Marylebone remarked, "The divine right of majorities is just as fallacious in conception as the doctrine of the divine right of king." ${ }^{\prime 4}$ Likewise, Mr Justice Dickson observed that "Forms of government may need protection from dangers likely to arise from within the institutions to be protected." ${ }^{\prime 4}$ Every constitution rests on some fundamental values that are expressed through the text of the constitution. In constitutional review, the judiciary is to remain faithful to these values as expounded through a process of reasoning and to ensure that these values are not lost as a result of majority prejudice. As Lord Bingham of Cornhill observed, "there are some rules which no government should be free to violate without legal restraints." ${ }^{16}$ In discharging its duties independently, it is inevitable that the judiciary will sometimes deliver judgments that are unpopular, controversial or political. The US

\footnotetext{
${ }^{43} 5$ US 137 (1803). See also Alexander Hamilton, Federalist Papers No 78, 14 June 1788.

${ }^{44}$ Lord Hailsham, A Sparrow's Flight: The Memoirs of Lord Hailsham of St Marelybone (Fontana: Marper Collins Publishers, 1990), p 392.

${ }^{45}$ Australian Communist Party v The Commonwealth (1951) 83 CLR 1 at 187. See also Bokhary, "The Rule of Law in an Evolving Democracy" (2010) 16 Canterbury Law Review 225, at 233-234.

${ }^{46}$ Tom Bingham, The Rule of Law (Allen Lane, 2010), p 170.
} 
Supreme Court has recently upheld by a bare majority the right of same sex couples to marry. ${ }^{47}$ In a less colourful judgment, the Hong Kong Court of Final Appeal has upheld the right of a transsexual to marry. ${ }^{48}$ It has also struck down a 7-year residential requirement for eligibility to social welfare on the basis that it constituted a disproportionate restriction to the right to social welfare of the new arrivals. ${ }^{49}$ Crossing to the other side of the line, the Court of Final Appeal has upheld a controversial criminal offence of desecrating national flag on a narrow basis that this restricted only the form and manner and not the content of speech, ${ }^{50}$ and in another case the Court held that the stay of foreign domestic helpers in Hong Kong did not qualify as "ordinary residence", thereby denying them the opportunity to acquire a right of abode in Hong Kong irrespective of how long they have lived in the territory. ${ }^{51}$ The real issue is not whether the decision of the court is in accord with or against the popular sentiment, but whether the court has applied the law in good faith and acted in accordance with law. Of course, this does not mean that the judiciary is free to legislate. As Mr Justice Bokhary points out, the judiciary indeed exercises great self-restraints in exercising such power. ${ }^{52}$ These restraints include adopting a remedial interpretation such as the techniques of reading down or reading in legislation and preserving statutes as far as constitutionally possible. The court may also suspend an unconstitutional provision in order to give time to the Government to introduce necessary remedial legislation or legislative amendments. ${ }^{53}$ In all these cases, the courts made a decision on the legal questions. Their decisions may involve policy or may have political ramifications, but the courts remain politically neutral. As argued above, the legitimacy of the judiciary lies not in the ballots or popularity of its decisions, but in the openness of the judicial process, the fair conduct of the hearing, the power of its reasoning in its written judgments,

\footnotetext{
${ }^{47}$ Obergefell v Hodges, Director, Department of Health, 576 US 1 (2015).

${ }^{48}$ W v Registrar of Marriages (2013) 16 HKCFAR 112.

${ }^{49}$ Kong Yunming v Director of Social Welfare (2013) 16 HKCFAR 950.

${ }^{50}$ HKSAR v Ng Kung Siu (1999) 2 HKCFAR 442.

${ }^{51}$ Vallejos v Commissioner of Registration (2013) 16 HKCFAR 45.

${ }^{52}$ See Bokhary, $\mathrm{n} 45$ above.

${ }^{53}$ The Court of Final Appeal has resorted to this technique on a number of occasions: Koo Sze Yiu v Chief Executive (2006) 9 HKCFAR 441 (allowing the Government 8 months to introduce legislation on covert surveillance), W v Registrar of Marriages (2013) 16 HKCFAR 112 (allowing Government 12 months to introduce detailed legislation to regulate issues arising from transgender marriages). See also Re Manitoba Language Rights [1985] 1 SCR 721 and A v Her Majesty's Treasury [2010] 2 WLR 378.
} 
and the neutrality and independence of the judiciary. This is their constitutional role; this is what the rule of law entails.

\section{The Epilogue}

The rule of law bears a special significance in Asia where there is a prevalence of developing economies in the Region and where there exists a great variety of political systems, ranging from military dictatorship, constitutional monarchy, one-party state, evolving democracy and full democracy. The diversity in political systems makes it difficult to have any consensus on democracy. Yet there is a widespread acceptance of the concept of the rule of law, which is perceived to have a functional dimension. Rule of law is generally accepted as an important condition for economic development, and this provides an incentive to improve the rule of law in the country. On this account, the rule of law may provide the foundation for bridging the chasms among Asian societies. Indeed, many Asian jurisdictions are prepared to move towards a law-abiding state through the enactment of legislation. At the same time, there is an awkward silence regarding the implementation of the law, and it is not unusual to have a huge gap between what the law says and what the practice is. In moving towards the ideal of the rule of law, two challenges stand out. The first common challenge is that there is a weak, sometimes corrupt, and sometimes compliant, judiciary. It is argued that an independent judiciary is essential to the rule of law, whatever be the legal or political system. A key to economic development lies in the motivation of the people and the liberation of incentives and creativity of the people. In the course of economic development there are bound to be conflicts between the state and the people. The judiciary stands between the state and the people. It ensures a secured environment for the people whose lives would not be disrupted by the exercise of arbitrary powers by the State, and maintains a proper balance between the interests of the state and of the people. Yet the judiciary will be able to give effect to the rule of law only when it is independent of the state. Unlike the two other branches of the government, the legitimacy of the judiciary lies not in the ballot box, but in its transparency, rationality, fairness and independence. In this sense, the rule of law can exist and even prevail in 
an evolving democracy. ${ }^{54}$ The economic success of Hong Kong is a prime example, as its success owes much to the prevalence of the rule of law, notwithstanding its limited democracy. There are inevitably disputes and struggles in the society, but these "are conducted peacefully, in a democratic spirit, with tolerance and with reason for hope. ${ }^{\prime \prime 5}$ The second common challenge is the hesitation of the state, or the ruling party, to be bound by the law. Ironically, this was what prompted the Magna Carta 800 years ago, and sadly this is still the concern today, albeit in a more sophisticated manner. Very few states these days would argue openly that they are above the law; yet the interpretation or administration of the law lies in the hands of the state so that law could mean what the state wants it to mean. Interpretation of the NPCSC in China is one such example. It does not necessarily mean that the Government is abusive; it may just be paternalistic and reluctant to give away its own supremacy. However, unless the Government truly accepts the supremacy of the law, which necessarily means giving up its own supremacy and subjecting itself to a set of objective norms that can be impartially ascertained and enforced, there is still a long way to achieve the goal of the rule of law. In the current climate of centralisation of power in China, the need for such change of attitude is particularly pertinent. There are reasons for optimism in the long run, as China has gone too far now in its reform to allow a reversal, but in the immediate future, China is in its periodic cycle of "one step forward, two steps back, and the prospect of its fully embracing the rule of law is far from being optimistic.

\footnotetext{
${ }^{54} \mathrm{Mr}$ Justice Bokhary argued that "democracy and the rule of law are natural allies, and should operate as such. But that is not to say that they will always run along parallel lines. In practice they will often criss-cross." He argued that an independent judiciary is the key, and the judiciary could bring democracy and the rule of law together under certain conditions, including its independent administration of the law and the exercise of selfrestraints in constitutional review: see Bokhary, n 45 above, at 241.

55 lbid, at 227.
} 